\title{
PERANCANGAN SOAL BERBASIS TEKNOLOGI SEBAGAI UPAYA MENUNJANG PEMBELAJARAN DARING BAGI GURU-GURU BAHASA MANDARIN SE MALANG RAYA
}

\author{
Amira Eza Febrian Putri'), Aiga Ventivani'1), Okti Rjeky'), Sunarti'1) \\ 1)Jurusan Sastra Jerman, Program Studi Pendidikan Bahasa Mandarin, Fakultas Sastra, Universitas Negeri Malang, \\ Malang, Jawa timur, Indonesia \\ Corresponding author : Amira Eza Febrian Putri \\ E-mail : febrian.putri.fs@um.ac.id
}

Diterima 21 November 2021, Direvisi 10 Desember 2021, Disetujui 10 Desember 2021

\begin{abstract}
ABSTRAK
Upaya pendidik dalam memenuhi tuntutan pendidikan abad 21 saat ini telah menghadapi tantangan berat yaitu adanya pandemi. Pola pembelajaran yang biasanya dilakukan secara tatap muka, mau tidak mau kini harus berjalan dengan cara daring. Ketidaksiapan ini menimbulkan berbagai masalah yang ditemukan di lapangan antara lain ketidaktercapaian tujuan pembelajaran, kesulitan penyampaian materi pembelajaran, kurangnya interaksi dengan siswa dalam proses pembelajaran, kualitas pemberdayaan sarana dan elemen dalam pembelajaran yang terbatas, terbatasnya pengetahuan tentang penggunaan media yang sesuai dengan kondisi saat ini. Sedangkan dari prespektif siswa, terdapat masalah yang sering dihadapi ketika pembelajaran daring yaitu siswa merasa jenuh karena pembelajaran dan penugasan yang monoton, tagihan tugas yang menumpuk, pembelajaran tidak semenyenangkan pembelajaran tatap muka, mengantuk karena terlalu lama menyimak penjelasan guru via online sinkron, dan sulitnya jaringan internet. Pelatihan perangcangan soal berbasis teknologi ini dilakukan sebagai upaya meningkatkan kecakapan guru terkait pembuatan aktifitas daring, khususnya tes dalam bentuk kuis online yang lebih menarik daripada sekedar penugasan manual. Adapun kegiatan dalam pengabdian berupa (1) pembelajaran daring; (2) masalah yang terjadi dalam pembelajaran daring; (3) pembelajaran daring yang ideal; (4) pemanfaatan teknologi dalam tes dan latihan. Hasil dari kegiatan pelatihan ini menunjukkan, dengan aplikasi quizizz, proprofs, dan $i$ spring suite guru dapat menumbuhkan minat dan motivasi dalam pembelajaran bahasa Mandarin, serta tercipta pembelajaran lebih bervariasi yang belum pernah dilakukan oleh guru sebelumnya.
\end{abstract}

Kata kunci: pelatihan; pembelajaran daring; guru; bahasa mandarin.

\begin{abstract}
Educators' efforts to meet the demands of 21st century education have faced a severe challenge: pandemics. Learning patterns that are usually done face-to-face, inevitably now have to run in an online way. This unpreparedness raises various problems found in the field including inability of learning objectives, difficulty in delivering learning materials, lack of interaction with students in the learning process, quality empowerment of facilities and elements in limited learning, limited knowledge of media use in accordance with current conditions. While from the perspective of students, there are problems that are often faced when online learning is that students feel saturated because of monotonous learning and assignments, piling up assignment bills, learning is not as enjoyable as face-to-face learning, sleepiness because it is too long to listen to the teacher's explanation via online sync, and the difficulty of the internet network. This technology-based training is done as an effort to improve the skills of teachers related to the creation of online activities, especially tests in the form of online quizzes that are more interesting than just manual assignments. The activities in this training are (1) online learning; (2) problems that occur in online learning; (3) ideal online learning; (4) utilization of technology in tests and exercises. The results of this training activity showed that with quizizz applications, proprofs, and i spring suites teachers can foster interest and motivation in Mandarin language learning, as well as create more varied learning that has never been done by teachers before.
\end{abstract}

Keywords: training; online learning; teacher; mandarin.

\section{PENDAHULUAN}

Pandemi Covid-19 mengakibatkan perubahan yang luar biasa. Seolah seluruh jenjang pendidikan 'dipaksa' bertransformasi untuk beradaptasi secara tiba-tiba melakukan pembelajaran dari rumah. Ini tentu bukanlah hal 
yang mudah, karena baik guru maupun siswa belum sepenuhnya siap dengan perubahan ini. Ketidaksiapan ini menimbulkan berbagai masalah yang ditemukan di lapangan antara lain ketidaktercapaian tujuan pembelajaran, kesulitan penyampaian materi pembelajaran, kurangnya interaksi dengan siswa dalam proses pembelajaran, kualitas pemberdayaan sarana dan elemen dalam pembelajaran yang terbatas, terbatasnya pengetahuan tentang penggunaan media yang sesuai dengan kondisi saat ini. Sedangkan dari prespektif siswa, terdapat masalah yang sering dihadapi ketika pembelajaran daring yaitu siswa merasa jenuh karena pembelajaran dan penugasan yang monoton, tagihan tugas yang menumpuk, pembelajaran tidak semenyenangkan pembelajaran tatap muka, mengantuk karena terlalu lama imenyimak penjelasan guru via online sinkron, dan sulitnya jaringan internet.

Upaya pendidik dalam memenuhi tuntutan pendidikan abad 21 saat ini telah menghadapi tantangan berat yaitu adanya pandemi. COVID-19 memberikan tantangan baru bagi dunia, tidak hanya segi kesehatan dan ekonomi, segi pendidikanpun harus menyesuaikan kebijakan yang dibuat Pemerintah untuk mengurangi lajunya penyebaran virus ini. Pola pembelajaran yang biasanya dilakukan secara tatap muka, mau tidak mau kini harus berjalan dengan cara daring. Pada dasarnya, pembelajaran daring merupakan terobosan baru yang sesuai untuk mencapai pendidikan abad 21. Pendidikan abad 21 harus dapat membekali peserta didik dengan keterampilan belajar dan berinovasi, keterampilan menggunakan dan memanfaatkan media informasi, dan kecakapan hidup untuk bekerja dan berkontribusi pada masyarakat. Keterampilanketerampilan inilah yang dinamakan konsep kecakapan hidup abad 21 (Kemendikbud, 2017). Untuk dapat mencapai keterampilan di atas, diperlukan kecakapan pendidik untuk memberikan inovasi berupa pengajaran yang dapat mengimplementasikan teknologi dalam pembelajaran yang menarik.

Pendidikan jarak jauh dapat didefinisikan sebagai proses pembelajaran yang tidak memperhitungkan ruang dan waktu pembelajaran dan bersifat mandiri untuk pengembangan peserta didik dengan menggunakan metode dan teknik maupun media dalam kegiatan pembelajaran (Kör et al., 2014)(Isman, 2017)(Iskenderoglu et al., 2012), kegiatan e-learning sangat fleksibel karena dapat diakses dan melakukan pembelajaran tanpa terhalang waktu dan tempat, e-learning memberikan keleluasaan pada pengajar agar dapat memberikan akses kepada peserta didik untuk mendapatkan referensi lain terkait dengan materi pembelajaran, hal ini sangat berguna untuk meningkatkan kualitas pembelajaran (Pardede, 2011)(Yaniawati, 2013)(Lee et al., 2019). Banyak media pembelajran yang dapat menunjang pembelajaran jarak jauh seperti daring (elearning) dengan perkembangan internet membuat PJJ jauh lebih mudah dan juga menggunakan teknologi untuk menunjang kegiatan pembelajaran (Othman et al., 2012)(Darmayanti et al., 2007).

$$
\text { Namun dalam penerapannya, }
$$

pembelajaran secara daring banyak sekali menemui kendala yaitu kurangnya peralatan, personel, sumber daya, dan keterbatasan teknologi pendidikan, serta keterampilan dan kualitas yang dimiliki pendidik belum mencukupi. Dari hasil wawancara ditemukan bahwa sebagian besar aktifitas latihan siswa dilakukan dengan cara penugasan, pengiriman soal melalaui whatsapp, email, wechat, telegram untuk dikerjakan oleh siswa. Pembelajaran seperti ini tentu tidak menumbuhkan minat dan motivasi siswa. Untuk itu, diperlukan adanya sinergi yang baik antara pengajar dengan peserta didik untuk lebih menggali informasi dan memanfaatkan teknologi yang dapat membantu dalam pelaksanaan pembelajaran daring.

Dari observasi lapangan, dalam pembelajaran bahasa Mandarin sebagian besar hanya mengacu pada buku teks yang digunakan, dan tidak menggunakan referensi lain. Hal ini menjadi masalah ketika menjalankan pembelajaran daring. Untuk itu diperlukan wawasan mengenai aplikasiaplikasi yang dapat digunakan untuk menunjang pembelajaran dan menyusun tes secara online.

Solusi dari permasalahan di atas yaitu perlu dilakukan langkah yang signifikan dengan tujuan pembelajaran daring yaitu membuat tes atau latihan soal dengan memanfaatkan aplikasi dan teknologi. Aplikasi yang sesuai untuk digunakan pada pembelajaran bahasa Mandarin secara daring antara lain; Quizizz, iSpring suite, dan proProfs. Aplikasi tersebut bisa didefinisikan sebagai soal yang bisa langsung dikerjakan melalui gawai atau laptop, dengan syarat tersambung internet, dan hasilnya bisa langsung muncul begitu soal selesai dikerjakan. Setiap aplikasi memiliki keunggulan dan keunikan masing-masing sehingga menarik untuk dipelajari penggunaannya agar bermanfaat dalam proses pembelajaran daring di masa pandemi.

Pelatihan perangcangan soal berbasis teknologi ini bertujuan meningkatkan kecakapan guru terkait pembuatan aktifitas 
daring, khususnya tes dalam bentuk kuis online yang lebih menarik daripada sekedar penugasan manual. Dengan aplikasi quizizz, proprofs, dan $i$ spring suite diharapkan guru dapat menumbuhkan minat dan motivasi siswa dalam pembelajaran bahasa Mandarin. Ketiga aplikasi ini memungkinkan guru membuat soal disertai dengan gambar, video, link, serta audio. Tampilan yang menarik memungkinkan siswa merasa mereka bukan sedang mengerjakan soal, namun sedang bermain game. Sehingga, akan timbul rasa enjoy dalam mengikuti pembelajaran. Dengan pemanfaatan penyusunan soal berbasis teknologi, diharapkan akan tercipta pembelajaran lebih bervariasi yang belum pernah dilakukan oleh guru. Misalnya, guru membuat kuis yang memungkinkan mahasiswa beranggapan bahwa mereka tidak sedang belajar, melainkan sedang bermain game. Dalam hal ini, guru lebih persuasif karena membuat siswa semakin tertarik dengan pembelajaran tersebut. Sehingga dengan adanya penerapan penyusunan soal berbasis teknologi, membuat siswa tidak merasa bosan dalam mengikuti pembelajaran secara daring.

\section{METODE}

Metode yang digunakan dalam pelaksanaan pelatihan perancangan soal berbasis teknologi sebagai upaya menunjang pembelajaran daring bagi guru-guru bahasa Mandarin se Malang Raya yaitu metode pembimbingan. Adapun langkah-langkah dalam perancangan pelatihan ini adalah sebagai berikut:

\section{Perencanaan Kegiatan}

Pelaksanaan perancangan kegiatan pelatihan antara lain; (a) Menghubungi guru Bahasa Mandarin di sekolah-sekolah yang menjadi mitra pelatiha melalui ketua MGMP Bahasa Mandarin kota Malang. Tahap ini digunakan untuk berkoordinasi membahas rencana kegiatan pelatihan; (b) mengadakan sosialisasi terkait kegiatan pelatihan perancangan soal berbasis teknologi sebagai upaya menunjang pembelajaran daring bagi guru-guru bahasa Mandarin se Malang Raya. Sosialisasi ini bertujuan untuk menjaring informasi tentang kesediaan guru-guru bahasa Mandarin se Malang Raya. Sosialisasi dilaksanakan secara daring menggunakan zoom meeting. Setelah tahap sosialisasi, tim pelaksana menyebarkan angket untuk menjaring informasi terkait permasalahan yang dihadapi pada saat proses pembelajaran khususnya pada masa pandemi; (c) Merancang teknis kegiatan pelatihan.
Tabel 1. Penyusunan.

\begin{tabular}{|c|c|c|c|}
\hline $\begin{array}{c}\text { tangg } \\
\text { al }\end{array}$ & $\begin{array}{c}\text { Tahap } \\
\text { kegiatan }\end{array}$ & $\begin{array}{c}\text { Pelaksa } \\
\text { na }\end{array}$ & Target \\
\hline $\begin{array}{c}3 \\
\text { maret } \\
2021\end{array}$ & $\begin{array}{l}\text { Studi } \\
\text { literatur }\end{array}$ & Amira & Draf \\
\hline $\begin{array}{c}31 \\
\text { maret } \\
2021\end{array}$ & $\begin{array}{c}\text { Survey } \\
\text { lapangan }\end{array}$ & Aiga & data \\
\hline $\begin{array}{l}1 \text { april } \\
2021\end{array}$ & $\begin{array}{l}\text { Perancan } \\
\text { gan } \\
\text { jadwal } \\
\text { kegiatan }\end{array}$ & $\begin{array}{l}\text { Amira } \\
\text { dan } \\
\text { Sunarti }\end{array}$ & $\begin{array}{l}\text { Jadwal } \\
\text { dan } \\
\text { susunan } \\
\text { acara }\end{array}$ \\
\hline $\begin{array}{c}16 \\
\text { april } \\
2021\end{array}$ & $\begin{array}{c}\text { Perencan } \\
\text { aan teknis } \\
\text { kegiatan }\end{array}$ & Octi & $\begin{array}{c}\text { Rancang } \\
\text { an } \\
\text { kegiatan }\end{array}$ \\
\hline
\end{tabular}

\section{Pelatihan}

Materi yang disampaikan yaitu pemanfaatan teknologi dalam pembuatan soal latihan dan tes dalam pembelajaran bahasa Mandarin dengan kisi-kisi materi sebagai berikut; (a) pembelajaran daring; (b) masalah yang terjadi pada pembelajaran daring; (c) pembelajaran daring yang ideal; (d) pemanfaatan teknologi dalam tes dan latihan. Aplikasi yang digunakan dalam pelatihan ini yaitu Quizizz, i spring suite, dan proprofs.

Tabel 2. Pelatihan

\begin{tabular}{|c|c|c|}
\hline Tanggal & $\begin{array}{c}\text { Tahap } \\
\text { kegiatan }\end{array}$ & $\begin{array}{c}\text { Penanggung } \\
\text { jawab }\end{array}$ \\
\hline \multirow[t]{4}{*}{$\begin{array}{c}14 \\
\text { Agustus } \\
2021 \\
\end{array}$} & $\begin{array}{l}\text { Pengarahan } \\
\text { teknis }\end{array}$ & Amira \\
\hline & $\begin{array}{c}\text { Penyampaian } \\
\text { materi }\end{array}$ & Amira \\
\hline & $\begin{array}{c}\text { Pendampingan } \\
\text { praktik }\end{array}$ & Amira \\
\hline & $\begin{array}{c}\text { Penyebaran } \\
\text { angket }\end{array}$ & Sunarti \\
\hline
\end{tabular}

\section{Analisis Pelaksanaan Pengabdian}

Tahap akhir yang dilakukan yaitu analisis dan evaluasi. Analisis bertujuan untuk mengetahui kesimpulan kegiatan pengabdian, evaluasi dilakukan berdasarkan hasil angket.

Tabel 3. Perencanaan tahap analisis

\begin{tabular}{cccc}
\hline $\begin{array}{c}\text { Tangg } \\
\text { al }\end{array}$ & $\begin{array}{c}\text { Tahap } \\
\text { kegiatan }\end{array}$ & $\begin{array}{c}\text { Penangg } \\
\text { ung } \\
\text { jawab }\end{array}$ & target \\
\hline 20 & Analisis & Amira & kesimp \\
Agustu & $\begin{array}{c}\text { pelaksan } \\
\text { dan } \\
\text { aan } 2021\end{array}$ & $\begin{array}{c}\text { sunarti } \\
\text { sunan }\end{array}$ & \\
\hline 1 & Evaluasi & Octi & $\begin{array}{c}\text { Data } \\
\text { septem }\end{array}$ \\
ber & & & angket \\
2021 & & & \\
\hline
\end{tabular}




\section{HASIL DAN PEMBAHASAN}

Pelatihan perancangan soal berbasis teknologi dihadiri oleh guru-guru bahasa Mandarin se-Malang Raya melalui platform zoom. Kegiatan ini berlangsung selama 2 jam dengan susunan acara sebagai berikut.

1. Pembukaan

2. Penyampaian materi

3. Praktek oleh guru

4. Sesi tanya jawab

5. Pengisian link presensi dan sertifikat

6. Penutupan

Materi yang disampaikan meliputi pembelajaran daring, masalah yang terjadi pada pembelajaran daring, pembelajaran daring yang ideal, dan pemanfaatan teknologi dalam tes dan latihan. Aplikasi yang digunakan dalam pembuatan latihan soal adalah aplikasi quizizz, proprofs, i spring suite.

Quizizz merupakan sebuah web tool untuk membuat permainan kuis interaktif yang digunakan dalam pembelajaran di kelas. Aplikasi ini dapat digunakan dalam pembelajaran di kelas dan dapat digunakan untuk evaluasi pembelajaran. Quizizz dapat diakses di playstore bagi pengguna android, sehingga dalam penggunaannya lebih praktis. Quizizz dapat memberikan data dan statistik tentang hasil kinerja siswa secara langsung. Quizizz tidak hanya dapat dikerjakan saat pembelajaran di kelas saja, tetapi juga dapat dibuat soal untuk pekerjaan rumah (PR), sehingga dapat dimainkan kapan saja dan dimana saja oleh siswa asalkan tidak melebihi batas waktu yang sudah ditentukan.

Dengan quizizz, siswa akan merasa ditantang karena pada akhir tes terdapat skor yang diperoleh dengan menjawab secara cepat dan tepat. Kecepatan akan mempengaruhi ranking antar siswa. Selain itu akan ada persaingan, karena quizizz langsung membuat ranking yang bersifat live antar peserta. Kelebihan dari quizizz adalah siswa tidak dapat mencontek sesama temannya, karena soal yang diberikan kepada siswa satu dengan yang lainnya telah diacak. Soal bisa dibuat dengan ketentuan waktu tertentu yang membuat siswa tidak punya kesempatan untuk bertanya dengan orang sekitar atau melihat buku catatan miliknya. Setelah mengerjakan kuis, siswa dapat mengetahui rangking yang dia dapat dari keseluruhan siswa yang mengerjakan soal tersebut. tidak hanya itu, siswa juga mengetahui soal dan jawaban yang betul dari soal yang telah dikerjakannya.

Keuntungan quizizz bagi guru adalah adanya grading otomatis yang memungkinkan guru mendapatkan nilai siswa secara langsung tanpa mengoreksi secara manual. Quiziz juga dapat membuat analisis butir soal, yang semuanya dapat diunduh berupa file excel. Sehingga akan otomatis tampak soal mana yang cukup sulit dikerjakan siswa, dan soal mana yang cukup mudah dikerjakan. Laporan yang dihasilkan cukup detail, setiap siswa akan dilaporkan jawaban benar-salahnya, serta prosentase pencapaian quiz untuk seluruh siswa. Dan yang menarik, hasil quiz setiap siswa dapat diemail ke orang tua siswa.

Proprofs adalah aplikasi berbasis web gratis yang dapat digunakan sebagai pembuat tes online ataupun survei. Tampilan proProfs menojolkan kesan elegan dan simple. Fitur yang terdapat di dalamnya cukup lengkap, selain itu kita dapat menambahkan video dalam soal yang kita buat. Hal yang unik dari proProfs adalah adanya sertifikat yang menunjukkan hasil tes yang telah dilakukan. Secara umum, cara penggunaan aplikasi ini sama dengan Quizizz, sehinga guru tidak menemukan kendala pada saat praktik pengamplikasian soal.

I spring suite merupakan alat authoring e-Learning serba guna yang memungkinkan guru membuat beragam tipe konten e-Learning. Dengan aplikasi iSpring Suite, guru dapat memasukkan kuis, survei, interaksi, simulasi dialog, atau perekaman layar langsung ke presentasi power point. Kelebihan aplikasi ini adalah guru dapat merancang pembelajaran hanya dengan satu alat yaitu power point.

Kegiatan pelatihan ini dilaksanakan pada tanggal 14 Agustus 2021 secara virtual dengan menggunakan zoom meeting. Para guru dibimbing untuk dapat memanfaatkan teknologi yaitu aplikasi pembuat soal untuk meningkatkan kualitas pembelajaran daring. Hasil yang dicapai melalui kegiatan pengabdian ini dituangkan dalam bentuk hasil kegiatan pada setiap tahap pelaksanaan yaitu pengarahan dan praktek. Jabaran setiap tahapan adalah sebagai berikut:

\section{Pengarahan}

Pada tahap awal, guru-guru diberikan pengarahan terkait pembelajaran daring, antara lain:

\section{Teori Pembelajaran Daring}

Pada tahap ini guru diberi penjelasan terkait teori-teori dan pandangan para ahli mengenai pengaruh pandemi dalam pembelajaran daring.

Teori dan pandangan para ahli terkait pandemi dan pembelajaran daring dibahas secara singkat untuk memberikan wawasan awal pada guru-guru. 


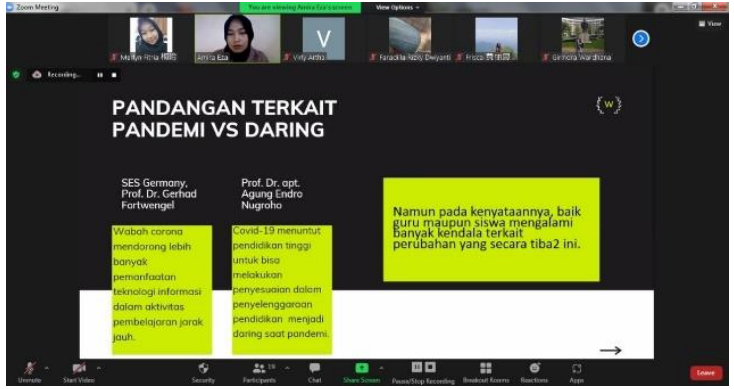

Gambar 1. Dokumentasi penjabaran materi

\section{Masalah yang Terjadi dalam Pembelajaran Daring}

Pada tahap ini para guru diberi penjelasan terkait hasil riset yang menunjukkan masalah-masalah yang sering terjadi dalam pelaksanaan pembelajaran daring.

Topik bahasan yang diangkat adalah hasil-hasil penelitian yang menunjukkan masalah yang dihadapi ketika pembelajaran daring dalam presepsi guru dan siswa.

\section{Pembelajaran Daring yang Ideal}

Tahap selanjutnya yaitu penjelasan mengenai pembelajaran daring yang ideal. Pada tahap ini guru diberikan wawasan bahwa aktivitas belajar dan pembelajaran online tidak selalu berbasis tugas dan tidak selalu $100 \%$ menggunakan virtual meeting.

Pembelajaran ideal yang diangkat dalam bahasan ini adalah blended learning. Dalam prosesnya, dijabarkan juga terkait pengaplikasian pembelajaran sinkron, asinkron, dan penugasan.

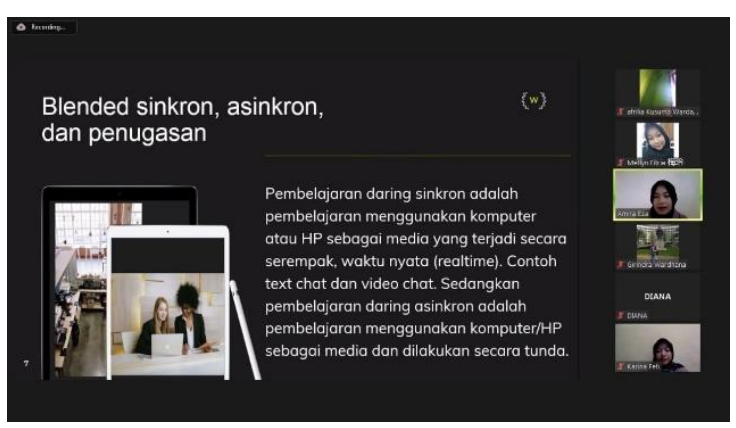

Gambar 2. Dokumentasi penjabaran materi

\section{Pemanfaatan Teknologi dalam Tes dan Latihan.}

Inti dari pelatihan ini terdapat pada tahap ini yaitu pengenalan tiga aplikasi pembuat soal dan latihan (Quizizz, i spring suite, dan proprofs) serta cara pengaplikasiannya.

Pada tahap ini para guru diberi tutorial lengkap mulai dari cara mengakses aplikasi, registrasi, langkah-langkah penggunaan, dan simulasi penginputan soal.

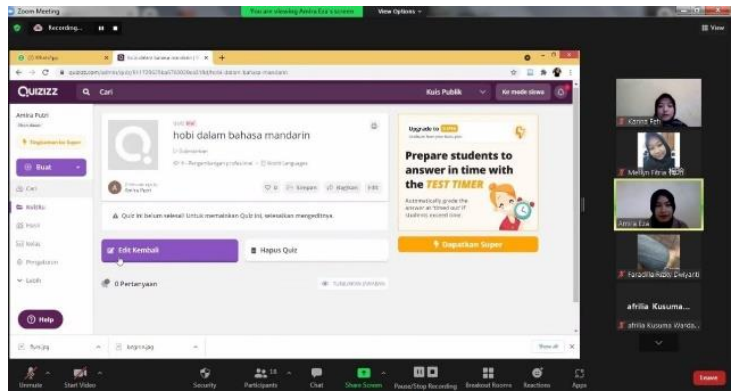

Gambar 3. Dokumentasi penjabaran materi

\section{Praktek}

Setelah diberikan gambaran berupa paparan pada tahap pengarahan, para guru mempraktekkan langsung pengaplikasian ketiga aplikasi tersebut.

Selain itu, pada tahap ini juga terdapat sesi tanya jawab terkait kesulitan yang dialami pada saat pengaplikasian soal dan diskusi. Setelah guru memahami langkah penggunaan aplikasi, para guru diperkenankan untuk mencoba mempraktekan pengetahuan yang telah di dapatkan secara mandiri. Para guru menyusun soal secara mandiri dengan memanfaatkan aplikasi berbekal ilmu yang telah didapatkan. Tes yang digunakan dibagi menjadi soal pilihan ganda, pilihan ganda kompleks, menjodohkan, isian singkat, dan uraian. Masing-masing bentuk tes tersebut akan diaplikasikan menggunakan ketiga aplikasi pembuat tes online yaitu Quizizz, iSpring suite, dan proProfs.

\section{SIMPULAN DAN SARAN}

Pelaksanaan pelatihan peranvangan soal berbasis teknologi bagi guru-guru bahasa Mandarin se Malang Raya membuahkan dampak positif. Berdasarkan hasil angket peserta merasa mendapatkan ilmu dan hal baru. Aplikasi yang digunakan dalam pelatihan ini dirasa sangat membantu guru dalam penerapan pembelajaran daring khususnya pemberian latihan atau kuis pada siswa. Peserta tertarik untuk menggunakan aplikasi yang digunakan dalam penelitian ini karena mudah diakses dan tutorial yan disampaikan sangat jelas dan rinci.

\section{UCAPAN TERIMAKASIH}

Atas dilaksanakannya kegiatan pengabdian yang didanai oleh Hibah Penerimaan Negara Bukan Pajak (PNBP) Fakultas Sastra Universitas Negeri Malang ini, saya berterima kasih kepada anggota peneliti atas upaya luar biasa mereka dalam membantu proyek ini dalam pengumpulan data dan transkripsi data. Selain itu, tidak lupa saya ucapkan terima kasih kepada MGMP Malang Raya, mahasiswa panitian kegiatan, dan kolega atas partisipasi 
dan dukungannya dalam membantu kelancaran kegiatan pengabdian ini.

\section{DAFTAR RUJUKAN}

Kemendikbud. 2017. Kurikulum 2013: Kompetensi dasar Sekolah Menengah Atas/Madrasah Aliyah. Menteri Pendidikan dan Kebudayaan Republik Indonesia.

Darmayanti, T., Setiani, M. Y., \& Oetojo, B. (2007). E-Learning pada pendidikan jarak jauh: konsep yang mengubah metode pembelajaran di perguruan tinggi di Indonesia. Jurnal Pendidikan Terbuka Dan Jarak Jauh, 8, 99-113.

Iskenderoglu, M., Iskenderoglu, T. A., \& Palanci, M. (2012). Opinion of Teaching Staff in Distance Education Systems, Regarding the Assessment and Evaluation Process. Procedia - Social and Behavioral Sciences, 46, 4661-4665. https://doi.org/10.1016/j.sbspro.2012.06. 314

Isman, M. (2017). Pembelajaran Moda dalam Jaringan (Moda Daring). The Progressive and Fun Education Seminar, 586-588

Kör, H., Aksoy, H., \& Erbay, H. (2014). Comparison of the Proficiency Level of the Course Materials (Animations, Videos, Simulations, E-books) Used in Distance Education. Procedia - Social and Behavioral Sciences, 141, 854-860. https://doi.org/10.1016/i.sbspro.2014.05. 150

Lee, K., Choi, H., \& Cho, Y. H. (2019). Becoming a competent self: $A$ developmental process of adult distance learning. Internet and Higher Education, 41(November 2018), 25-33. https://doi.org/10.1016/j.iheduc.2018.12. $\underline{001}$

Othman, M. S., Mohamad, N., Yusuf, L. M., Yusof, N., \& Suhaimi, S. M. (2012). An Analysis of e-Learning System Features in Supporting the True e-Learning 2.0. Procedia - Social and Behavioral Sciences, 56(Icthe), 454-460. https://doi.org/10.1016/i.sbspro.2012.09. $\underline{676}$

Pardede, T. (2011). Pemanfaatan e-learning sebagai media pembelajaran pada pendidikan tinggi jarak jauh. Seminar Nasional FMIPA UT 2011, 1, 55-60.

Yaniawati, R. P. (2013). E-Learning to Improve Higher Order Thinking Skills (HOTS) of Students. Journal of Education and Learning (EduLearn), 7(2), 109 https://doi.org/10.11591/edulearn.v7i2.

$$
\underline{225}
$$

